\title{
Sub-lethal effects of an oil pollution incident on breeding kittiwakes Rissa tridactyla
}

\author{
P. Walton ${ }^{1, *}$, C. M. R. Turner ${ }^{1}$, G. Austin ${ }^{2}$, M. D. Burns ${ }^{1}$, P. Monaghan ${ }^{1, * *}$ \\ ${ }^{1}$ Institute of Biomedical and Life Sciences, University of Glasgow, Glasgow G12 8QQ, United Kingdom \\ ${ }^{2}$ British Trust for Ornithology, The Nunnery, Thetford, Norfolk IP24 2PU, United Kingdom
}

\begin{abstract}
Kittiwakes from the colony closest to the site of the wreck of the 'Braer' oil tanker in Shetland, Scotland, in 1993 were studied in the breeding season following the spill. Sub-lethal effects of the spill on breeding kittiwakes were assessed by comparison with an extensive data set collected at the same site (Sumburgh Head) during the 3 yr prior to the spill. Breeding performance in 1993 was very similar to that in 1992, with relatively good breeding success and short, frequent foraging trips. However, haematological data revealed a significant level of anaemia in the breeding kittiwakes at Sumburgh in 1993 compared to birds sampled in the same year at control colonies elsewhere in Scotland. The return rate of adults to the Sumburgh colony between 1992 and 1993 was exceptionally low, and nest-site and mate fidelity also appeared low. This was not a consequence of reduced survival, but was due to some adults not breeding in 1 or 2 yr following the spill, and subsequently returning to breed at the colony in later years. Such behavioural disruption may have considerable consequences for the dynamics and structure of the colony.
\end{abstract}

KEY WORDS: Oil pollution - Seabird A Anaemia - Breeding performance Colony attendance $\cdot$ Annual survival Non-breeding

\section{INTRODUCTION}

The direct mortality of seabirds resulting from acute oil pollution has received considerable public and scientific attention (Dunnet 1982). However, crude oil contamination may have other sub-lethal effects which, while difficult to demonstrate unequivocally following specific incidents, could be of considerable importance at both the individual and population levels (see Anderson et al. 1996, Sharp 1996). Evaluation of sub-lethal effects of oil contamination on marine birds has been based largely on experimental studies in which birds are dosed (internally and/or externally) with oil. These studies have revealed a spectrum of changes in breeding behaviour and performance, including delays in egg laying and reductions in the pro-

- Present address: RSPB South and West Scotland, Unit 3.1, West of Scotland Science Park, Kelvin Campus, Glasgow G20 0SP, United Kingdom

- Addressee for correspondence.

E-mail: p.monaghan@udcf.gla.ac.uk portion of adults laying eggs, egg hatching success, chick fledging success and in the return rate of adults to the breeding colony in the subsequent breeding season (Ainley et al. 1981, Harvey et al. 1982, Fry et al. 1986, Butler et al. 1988). This variety of negative effects reflects the diversity of taxa under investigation, the range of dosages and methodologies employed, and the divergent chemical nature of the different crude oils used (Clark 1984). While such impaired reproductive performance due to physiological effects of sub-lethal oil contamination is likely to accompany real oil spills, there is little evidence for such effects in free-living birds following actual contamination incidents. The majority of post-spill studies involve birds that have been subjected to cleaning and rehabilitation procedures in addition to oiling itself, and it can therefore be difficult to separate the effects due to the cleaning operations from those due to oil ingestion (Eppley \& Rubega 1990, Anderson et al. 1996, Sharp 1996). However, one primary toxic effect that occurs consistently as a result of crude oil ingestion in birds is haemolytic anaemia (Leighton et al. 
1983). As disturbance of red blood cell function can affect other tissues, many of the recorded physiological and behavioural effects on birds may be secondary responses to a primary dysfunction of erythrocytes (Leighton et al. 1983). Anaemia is relatively simple to detect in blood samples and thus provides a nondestructive means of detecting physiological effects of crude oil exposure in wild birds.

In addition to direct sub-lethal effects, oil pollution could also affect birds indirectly by altering the avail ability of prey species. The reproductive patterns and foraging behaviour of seabirds are known to reflect fluctuations in abundance of principal prey species (e.g. Monaghan 1996). Crude oil is toxic to fish, and contamination can lead to substantial fish mortality (Stebbing et al. 1992), and also to alterations in fish physiology and behaviour that could affect their availability to seabird predators (e.g sandeel emergent behaviour, Pearson et al. 1984).

In January 1993, the oil tanker 'Braer' ran aground at Garths Ness in southern Shetland (Scotland) spilling 84000 tonnes of Gullfax crude oil (Ritchie \& O'Sullivan 1994). The direct mortality of seabirds following the spill is well documented. Mortality of kittiwakes Rissa tridactyla appeared relatively low, with 133 kittiwakes $18.6 \%$ of the total number of dead birds recovered, Monaghan 1994) being found dead on beaches immediately after the incident. The spill occurred 4 mo before the onset of kittiwake breeding, by which time most visible evidence of the spill had disappeared (authors' pers. obs.).

The seabird colonies at Sumburgh Head are the closest concentration of breeding seabirds to the wreck (approximately $4 \mathrm{~km}$ distant). Over the $3 \mathrm{yr}$ preceding the spill, 1990 to 1992, we conducted a detailed investigation into the responses of seabirds breeding at this site to changes in prey availability in the surrounding waters (see Monaghan 1996). During that period there were large differences between years in the population age structure and abundance of lesser sandeels Ammodytes marinus, the most important prey species for seabirds breeding in the area. Kittiwakes feed their chicks predominantly on 0-group sandeels. In 1990 these were extremely scarce near Sumburgh Head, but were several orders of magnitude more numerous in 1991, 1992 and 1993 (Monaghan 1996, Wright 1996). The studies from 1990 to 1992 thus gave us a detailed baseline data set, involving years of considerable variation in food availability, against which to assess sub-lethal effects of the spill on the seabirds subsequently breeding in the area.

In this paper we compare aspects of the breeding biology, behaviour, incidence of nonbreeding, and survival rate of kittiwakes before and after the spill. To investigate physiological effects of oil exposure in the kittiwakes breeding at Sumburgh in 1993 directly, we also compare haematological data on these birds with control samples collected at uncontaminated sites elsewhere in Scotland in this same year

\section{METHODS}

The study birds were breeding in a plot of approximately 50 nests on the west side of Sumburgh Head, at the southernmost tip of mainland Shetland $\left(59^{\circ} 51^{\prime} \mathrm{N}\right.$, $\left.1^{\circ} 16^{\prime} \mathrm{W}\right)$. Nest sites were numbered and mapped during nest-building (late April-early May). Breeding data were collected by daily observations from a wooden hide approximately $200 \mathrm{~m}$ from the plot. As no chicks fledged in 1990, analysis of data relating to chick parameters covers only 1991, 1992 and 1993. Accurate fledging period data were collected only in 1992 and 1993.

In each year, a sample of breeding adults was caught at the colony during incubation or chick rearing. Sex was determined using head-plus-bill length (Coulson et al. 1983). To facilitate visual discrimination of pair members from the hide, adults were plumage-marked with spots of picric acid dye on the crown, breast or tail. From 1991 onwards all captured adults were given a unique combination of 3 colour rings and 1 numbered monel ring. Observations of these birds were made throughout the breeding periods 1992-1995 to estimate survival and site fidelity.

Colony attendance of marked adults was assessed in 2 ways. Firstly, in 1990 and 1991, continuous hide watches (using a team of observers working $4 \mathrm{~h}$ shifts) were made during daylight hours on 14 and $13 \mathrm{~d}$, respectively, in units of 2 or 3 consecutive days spread through the breeding period. Secondly, in 1991, 1992 and 1993, a sample of adults was fitted with tailmounted radio transmitters ( 8 birds in 1991, 19 birds in 1992, 29 birds in 1993: sample sizes differ between analyses due to tag or receiver malfunction, and caught birds breeding outside study colony). Tags weighed approximately $1.5 \%$ adult body weight and were attached to the central retrices using 2 small, steelratcheted cable ties. Similar tags used in another study were found to have little effect on the behaviour of kittiwakes (Wanless \& Harris 1992). The subsequent presence of these adults at the colony was recorded automatically. This was achieved using low-power tags (designed and built in Glasgow by MDB), a lowsensitivity aerial close to the colony (signal not detectable $>200 \mathrm{~m}$ from the colony), and a Cedar Creek scanning receiver set to cycle through the frequencies of active (mounted) radio tags. Presence/absence data were stored digitally on a lap-top computer, with an additional hard-copy produced by a printer set to 
operate as a continuous pen recorder The 1991 absence duration and frequency data presented here are those from hide watches, as the radio monitoring system was under development in that year Other birds were also fitted with higher power radio tags (same size and weight) in 1990 and 1991 to determine foraging locations (see Wanless et al. 1992, Monaghan et al. 1994, Monaghan 1996). In these 2 years the breeding performance and absence durations of tagged and untagged birds were compared to assess effects of radio tags on these parameters: no significant effects were found (Mann-Whitney U-test, $\mathrm{p}>0.1$ ).

In other studies, short absences from the nest site (<30 min) by breeding kittiwakes have been excluded from analyses of foraging trip duration, because the recording method could not identify adults present in the colony, though not at the nest itself, or because it was deemed unlikely that these short trips involved foraging (Coulson \& Johnson 1993). In this study, in 1993 breeding kittiwakes were occasionally seen to forage $<1 \mathrm{~km}$ from the colony, and to feed chicks after relatively short foraging trips (authors' pers. obs.). Therefore, since it is likely that some shorter trips did involve prey capture, trips < 30 min long ( $15 \%$ of all trips) were included in the analysis for all years.

Breeding data figures presented in Fig. 1 are based on all nests studied in each year. Most nest sites were occupied in sequential years. As site fidelity is the norm in established kittiwake colonies (Coulson \& Thomas 1985), repeated measures analysis of variance (ANOVA) was used to compare breeding data across years, with each nest being considered as a single subject. Sites not occupied or monitored in all years were excluded from this analysis. Nests from which durations and frequencies of adult absences were measured were not consistent across years; nests studied depended on which adults were caught (for picric marking or radio-tag attachment), and this was as a random process. Consequently, we analysed these data using 1-way ANOVA on means per nest, with Scheffé pairwise multiple comparisons tests.

To determine whether kittiwakes in Shetland were anaemic during the 1993 breeding season, blood samples were taken under licence from captured breeding adults at the Sumburgh Head colony, and, for com-

Fig. 1. Rissa tridactyla. Mean ( $\pm \mathrm{SE}$ ) (A) laying date of the furst egg in each clutch, (B) clutch size, (C) proportion of eggs hatching per nest, (D) number of chicks tledging per nest and (E) fledging period, taken from first egg hatching until first chick fledging at the Sumburgh Head kittiwake colony during the 4 yr of the study. (O) Breeding season following the oil spill (1993)
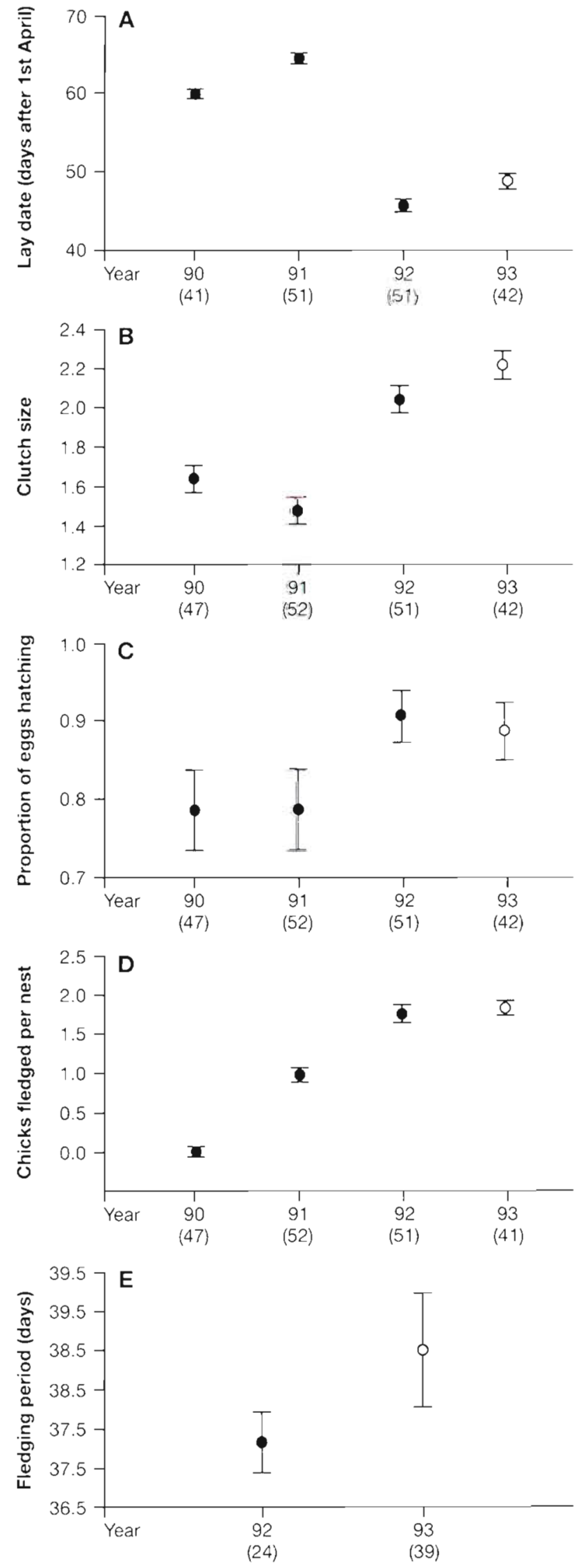
parison, from kittiwakes breeding at other (control) colonies elsewhere in Scotland: the Isle of May (56 $16^{\circ}$ ' N, $2^{\circ} 32^{\prime} W_{i} 412 \mathrm{~km}$ from Sumburgh) and Ailsa Craig (55 $15^{\prime} \mathrm{N}, 5^{\circ} 7^{\prime} \mathrm{W}$; $560 \mathrm{~km}$ from Sumburgh). All birds were sampled during chick rearing, by venipuncture of the tarsal vein and collection of expressed blood directly into 4 to 5 heparinized capillary tubes. All birds were released unharmed immediately after sampling. Sealed tubes were transported to the laboratory $(1$ to $3 \mathrm{~d})$, where they were held at $4^{\circ} \mathrm{C}$ until processing ( 0 to $3 \mathrm{~d}$ ). Samples were processed in 4 ways but constraints on the volumes of blood available from some birds prevented all samples being processed by all 4 methods. To determine the haematocrit, 1 capillary tube was centrifuged at $12000 \times g$ and the packed cell volume measured (percentage of blood volume occupied by cells). The blood from all other capillary tubes in a sample was combined. To determine the density of red blood cells, a portion of this sample was diluted 1:600 in formal citrate saline and red cells were counted using an improved Neubauer haemocytometer. To observe red blood cell morphology, a thin smear was made, methanol fixed and May-GrunwaldGiesma stained. To determine the percentage of cells that were reticulocytes, a portion of blood was mixed with 3 volumes of New Methylene Blue solution and incubated at $37^{\circ} \mathrm{C}$ for $20 \mathrm{~min}$; blood smears were made, dried and examined.

\section{RESULTS}

\section{Breeding timing and performance}

Fig. 1 shows overall mean $( \pm S E)$ values for breeding parameters for all nests studied in each year Table 1 gives the results of the repeated measures ANOVA tests (paired t-test for fledging period), comparing these parameters between years with multiple com- parisons tests. From Fig. 1 it can be seen that the prespill year in which kittiwake breeding performance most closely resembled the post-spill season (1993) was 1992. Of the parameters investigated, only mean laying date differed significantly between these 2 years, with birds in the 1993 breeding season laying significantly later than in 1992 (but significantly earlier than in 1990 and 1991). No kittiwake chicks fledged from the study area in 1990, when food supplies were very low. While the proportion of nests that fledged at least 1 chick did not differ significantly between 1991, 1992 and 1993 (Cochran $Q=5.17, \mathrm{n}=$ 35 nests, $\mathrm{df}=2, \mathrm{p}=0.08$ ), the mean number of young fledging per nest was greater in 1992 and 1993 than in 1991 (Table 1).

\section{Foraging behaviour}

The mean duration of trips made by adult kittiwakes during chick rearing differed significantly between years (Table 2). The largest, and only statistically significant, difference was between 1990 and subsequent years. Adult absences in 1993 did not differ significantly in duration from those in the previous 2 years. The mean daily frequency of trips also differed between years, and a temporal trend of sequentially increasing daily trip frequency was apparent from 1990 to 1993, when absences were most frequent (and of shortest duration, Table 2).

\section{Return rates and survival}

Of the 38 birds colour-ringed in 1991, 29 (76.3\%) returned to breed in the study colony in 1992. Fourteen additional birds were colour-ringed in 1992, and of the resulting total of 43 marked birds breeding in that year, $19(44.2 \%)$ returned to the colony to breed in

Table 1. Rissa tndactyla. Between-year tests on kittiwake breeding data from the Sumburgh Head study colony, $1990-1993$.

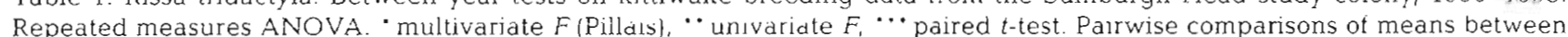
years are based on Scheffé multiple comparisons test

\begin{tabular}{|c|c|c|c|c|}
\hline & \multicolumn{3}{|c|}{ Repeated measures ANOVA } & $\begin{array}{l}\text { Pairwise comparisons } \\
\qquad(p<0.05)\end{array}$ \\
\hline Lay date & 28 & $250.71^{\circ}$ & $<0.001$ & $1992>1993>1990>1991$ \\
\hline Clutch & 32 & $18.87 \cdots$ & $<0.001$ & $(1992=1993)>(1990=1991)$ \\
\hline Prop. eggs hatching & 32 & $1.40^{\cdots}$ & $=0.248$ & $1990=1991=1992=1993$ \\
\hline No. fledged young ${ }^{\circ}$ & 35 & $16.00^{\cdots}$ & $<0.001$ & $(1992=1993)>1991$ \\
\hline Fledging period ${ }^{\mathrm{b}}$ & 14 & $t=-0.71 \cdots$ & $=0.488$ & $1992=1993$ \\
\hline
\end{tabular}


Table 2. Rissa tridactyla. Adult kittiwakes, breeding at Sumburgh Head, during chick rearing: mean (per year, per nest) duration and frequency of periods of colony absence, with 1-way ANOVA by year on nest means, and Scheffé palrwise comparison between years

\begin{tabular}{|c|c|c|c|c|c|c|c|}
\hline & \multicolumn{4}{|c|}{ Annual mean / n nests } & \multirow[t]{2}{*}{$F$} & \multirow[t]{2}{*}{$\mathrm{p}$} & \multirow{2}{*}{$\begin{array}{l}\text { Scheffé } \\
(p<0.05)\end{array}$} \\
\hline & 1990 & 1991 & 1992 & 1993 & & & \\
\hline $\begin{array}{l}\text { Trip duration } \\
\text { (min) }\end{array}$ & $\begin{array}{c}407.3 \pm 42.11 \\
\mathrm{n}=15\end{array}$ & $\begin{array}{c}137.8 \pm 11.6 \\
\mathrm{n}=19\end{array}$ & $\begin{array}{c}103.5 \pm 7.7 \\
n=18\end{array}$ & $\begin{aligned} 61.6 & \pm 8.4 \\
n & =13\end{aligned}$ & 49.78 & $<0.0001$ & $1990>(1991=1992=1993)$ \\
\hline Trips per day & $\begin{array}{c}1.4 \pm 0.25 \\
n=22\end{array}$ & $\begin{array}{c}3.7 \pm 0.22 \\
\mathrm{n}=19\end{array}$ & $\begin{array}{c}5.3 \pm 0.39 \\
\mathrm{n}=18\end{array}$ & $\begin{array}{c}8.2 \pm 1.19 \\
\mathrm{n}=14\end{array}$ & 27.62 & $<0.0001$ & $1990<1991<1992<1993$ \\
\hline
\end{tabular}

1993, the breeding season following the oil spill. However, in the 1994 breeding season, an additional 8, and in 1995 a further 3 , of the 43 marked birds present in 1992 were recorded in the colony, these individuals having not been present in the intervening period. Therefore, a minimum of 30 of the $43(69.8 \%) 1992$ birds survived the 1992-1993 winter. To adjust the number of birds sighted 1 to 2 yr after 1993 for natural mortality likely to have occurred in that time, we used the $76.3 \%$ survival rate recorded between 1991 and 1992 as a pre-spill baseline. Then, the 8 birds seen in 1994 represent 10 birds surviving 1992-1993, and the 3 seen in 1995 a further 5 birds surviving 1992-1993. Therefore, assuming no emigration, we estimate the survival of kittiwakes from the Sumburgh Head colony over the winter of the oil spill (1992-1993, with some not breeding in 1993 and 1994) to be approximately $79 \%$, very similar to the pre-spill figure of $76 \%$. However, $44 \%$ of the surviving birds did not breed in the year following the spill.

\section{Consistency in nest site and mate across years}

The proportion of breeding adults that retained the same nest site between 1992 and 1993 was less than half of that between 1991 and 1992. In the 2 subsequent years the proportion increased, but between 1994 and 1995 it was still well below the 1991-1992 level (Table 3 ). Though the sample size is small, the

Table 3. Rissa tridactyla. Nest site fidelity in colour-ringed kittiwakes breeding in the study colony at Sumburgh Head. No. birds known site: number of birds of known nest site in the 2 successive years. No. birds same site: number of birds breeding at the same site in the successive years

\begin{tabular}{|lcc|}
\hline Years & No. birds known site & No. birds same site (\%) \\
\hline $1991-1992$ & 21 & $19(90.5 \%)$ \\
$1992-1993$ & 16 & $7(43.7 \%)$ \\
$1993-1994$ & 13 & $6(46.2 \%)$ \\
$1994-1995$ & 9 & $6(66.7 \%)$ \\
\hline
\end{tabular}

data suggest a similar effect on the proportion of breeders retaining the same mate between successive years (Table 4 ).

For nests occupied across years, laying date was positively correlated between 1990 and 1991 ( $\mathrm{n}=37$ nests, $r=0.32, p<0.05$ ), and between 1991 and 1992 ( $\mathrm{n}=$ 44 nests, $r=0.39, p<0.01$ ), but not between 1992 and $1993(\mathrm{n}=38, \mathrm{r}=0.02, \mathrm{p}=0.91)$.

\section{Haematological parameters}

For the 2 control sites, there was no significant difference in any of the 3 haematological parameters, either between the sexes, or between birds from the 2 sites (Mann-Whitney $U, \mathrm{p}>0.05$ ). Therefore, data from these 2 sites were pooled in the following analysis. All 3 blood parameters differed significantly between control sites and Sumburgh. Packed cell volume was lower in Sumburgh breeders than the controls (Sumburgh mean $=55.98 \% \pm 2.0 \mathrm{SE}, \mathrm{n}=19 \mathrm{birds}$; control mean $=66.76 \% \pm 5.13 \mathrm{SE}, \mathrm{n}=13$ birds: $t=2.16, \mathrm{p}=$ 0.039), as was erythrocyte count (Sumburgh mean = $2.44 \pm 0.16 \times 10^{9} \mathrm{ml}^{-1} \mathrm{SE}, \mathrm{n}=29$ birds; control site mean $=3.71 \pm 0.38 \times 10^{9} \mathrm{ml}^{-1} \mathrm{SE}, \mathrm{n}=13$ birds: $t=3.69, \mathrm{p}=$ 0.001 ). Reticulocyte counts were significantly higher in kittiwakes breeding at Sumburgh Head (Sumburgh mean $=13.65 \% \pm 1.62 \mathrm{SE}, \mathrm{n}=16$ birds: control site mean $=6.94 \% \pm 2.40 \mathrm{SE}, \mathrm{n}=12$ birds: $t=2.41, \mathrm{p}=$ $0.024)$

Table 4. Rissa tridactyla. Mate fidelity of colour-ringed kittiwakes breeding in the Sumburgh Head study colony. No. birds mate known: number of birds for which the mate was known in 2 successive years. No. birds same mate: number of birds retaining the same mate between years

\begin{tabular}{|lcc|}
\hline Year & No. birds mate known & No. birds same mate \\
\hline $1991-1992$ & 8 & $8(100 \%)$ \\
$1992-1993$ & 4 & $2(50 \%)$ \\
$1993-1994$ & 1 & $0(0)$ \\
$1994-1995$ & 5 & $4(80 \%)$ \\
\hline
\end{tabular}




\section{DISCUSSION}

All breeding parameters investigated (with the exception of hatching success), and both the duration and frequency of adult absences, during chick rearing differed significantly $(p<0.05)$ between years, primarily because data from 1990, when food supply was Iow, differed from the other years. With respect to the oil spill year, only lay date and trip frequency differed significantly between 1992 and 1993: in 1993 adults laid approximately 3 d later, and made more trips per day during chick rearing, than in the previous year However, in contrast to the breeding performance parameters, return rate of marked adults between years was very low between 1992 and 1993. Significant differences in blood composition between samples from Sumburgh Head and those from the control site indicate that kittiwakes at the former site were relatively anaemic during the 1993 breeding season. Studies of sandeels in waters around Sumburgh Head showed no anomalous population decrease and no apparent toxic effects of oil contamination in this fish species during 1993 (Ritchie \& O'Sullivan 1994).

The pattern of between-year variation in clutch-size, fledging success, and duration and frequency of trips, appears to reflect variation in food availability, as in other studies of kittiwakes (e.g. Coulson \& Thomas 1985, Wanless \& Harris 1992). Hatching success did not differ significantly between years and was consistently high compared to a long term study at North Shields, in Northeast England (Coulson \& Wooler 1976 , Coulson \& Thomas 1985, Aebisher \& Coulson 1990). In contrast to that study, clutch size and chick survival were the main determinants of overall breeding success at Sumburgh. Other measures also revealed no detectable effect of the oil spill. Firstly, the magnitude of the difference in laying date between 1992 and 1993 was small compared to inter-annual differences at North Shields, where differences of more than $7 \mathrm{~d}$ between consecutive years were common (Coulson \& Thomas 1985). In comparison with the year of lowest food supply (1990), Sumburgh kittiwakes in 1993 Jaid approximately $10 \mathrm{~d}$ earlier, and at a time similar to 1992; thus the breeding season was not delayed following the oil spill. Secondly, relatively high parental foraging trip frequency during chick-rearing, which has been associated with relatively high fledging success of seabirds at Sumburgh and with plentiful food close to the colony (Hamer et al. 1993, Monaghan et al. 1994, Uttley et al. 1994, Monaghan 1996), was found in the current study; the significantly elevated trip frequency in 1993 compared to 1992 was thus apparently not a deleterious effect of oil pollution. Overall, the data on breeding performance and colony attendance suggest that foraging conditions were favourable in the breeding season following the oil spill. Of 56 kittiwake colonies monitored throughout Britain and Ireland in 1993, Sumburgh Head was the third most productive (Walsh et al. 1994).

The factor which did indicate a spill effect was the incidence of non-breeding. Annual return rates of individually marked kittiwakes generally give a reliable measure of annual survival (Coulson \& Wooler 1976). In the long-term study at North Shields it was rare for breeding kittiwakes to miss $1 \mathrm{yr}$, and subsequently return to rejoin the breeding population. No birds were recorded as missing $2 y r$ before returning to breed; annual return rate varied between years, but never fell below $60 \%$ and the overall mean was $>80 \%$ (Aebischer \& Coulson 1990). Also, in a 6 yr study of a different, sharply declining kittiwake colony, the lowest inter-annual return rate was $62 \%$ (Danchin \& Monnat 1992). Therefore, the $44 \%$ return rate between 1992 and 1993 at Sumburgh is exceptionally low. Furthermore, the fact that this low return rate does not represent low survival, but is a consequence of adults missing one or more breeding attempts, appears to be unusual for this species (see Boulinier \& Danchin 1996). Given that feeding conditions were relatively good in both 1992 and 1993 (Wright 1996), it is likely that this anomalous pattern of colony occupation is a consequence of the oil spill in January 1993. The reduced return rate of adults in 1993 was likely to be responsible for the elevated level of nest-site change and disruption of breeding pairs seen in that year.

We suggest that the factor responsible for missed breeding is an altered physiological state caused by oil ingestion. Obviously, blood samples from those birds that were absent in 1993 could not be obtained. However, samples from those adults that did return, and which were therefore possibly the least affected by oil contamination, revealed a significant, sub-lethal level of anaemia. Reduced erythrocyte count and packed cell volume indicates a reduction in erythrocyte density in the blood, and an elevated level of reticulocytes (the cellular precursors of erythrocytes) is characteristic of haemolytic anaemia. While the breeding performance of these adults was not altered, it is possible that the more severely affected birds did not breed in the year following the spill. These effects could come about through impaired endocrine function, which can disrupt many aspects of the birds' behaviour and physiology (Peakall et al. 1981), and such apparent non-breeding following oiling has also been reported in brown pelicans Pelecanus occidentalis (Anderson et al. 1996).

Blood samples from 3 other seabird species breeding at Sumburgh in 1993 (Arctic terns, common guillemots and shags) were not significantly different (in the same 3 blood composition measures) from control samples 
(Monaghan 1996). These 3 species, and kittiwakes, all feed predominantly on lesser sandeels during the breeding season at Sumburgh (Wright 1996). Guillemots and shags are pursuit divers and can obtain prey from depths that are beyond the reach of kittiwakes. Arctic terns, however, are surface feeders, and catch sandeels in the same (uppermost) part of the water column as kittiwakes. If kittiwakes became contaminated with oil-derived toxins by ingesting contaminated prey, it is likely that Arctic terns, and possibly common guillemots and shags, would also have displayed similar levels of anaemia. This, coupled with the low levels of polyaromatic hydrocarbons found in sandeels from Shetland waters during the 1993 seabird breeding season (Ritchie \& O'Sullivan 1994), suggests that it is unlikely that the anaemia in kittiwakes was a result of ingestion of contaminated prey. Unlike the other 3 species from which blood samples were analysed, kittiwakes build nests of mud, which they collect from a variety of sources. Birds from the study colony were seen to collect mud regularly from a small bog approximately $100 \mathrm{~m}$ from the colony, and from the edges of freshwater lagoons on Scatness Point (approximately $2 \mathrm{~km}$ distant, and closer to the wreck site). Terrestrial substrates at both of these sites were heavily contaminated during the spill (Miles 1994), and both are isolated from marine weathering effects. Kittiwakes carry nesting material in the bill, and it is possible that birds ingested oil from this site. If contamination was associated with this source, then the birds that did not breed presumably picked up relatively heavy contamination at the pre-breeding gatherings that occur on these freshwater areas.

In conclusion, this study demonstrates that superficial monitoring of breeding parameters may not show effects of an oil pollution incident on seabirds, but that less obvious sub-lethal physiological effects can occur. These effects on individuals can have important consequences, such as missed breeding years and disruption of colony structure, which could potentially have an impact at the population level. Furthermore, in assessing effects of oil pollution, it is essential to have pre-spill data that cover a broad range of background environmental conditions before effects on the behaviour and performance of breeding birds can be attributed, with confidence, to a specific pollution incident.

Acknowledgements. This work was supported by the Natural Environment Research Council. We thank C. Askew, S. Blackwood, L. Brown, A. Etheridge, R. Field, K. Hamer, M. Heubeck, W. Horn, D. Okill, T. Sawyer, M. Smith, D. Suddaby, H. Towll, J. Uttley, S. Wanless and S. Waugh for assistance with fleld work. We also thank J. Irvine for access to his land, and S. Young, for practical help. SNH Shetland assisted in providing logistıc support. We are grateful to N. Aslam for technical assistance and to the anonymous inferees for helpful comments. C.M.R.T is a Royal Society I, niversity Research Fellow.

\section{LITERATURE CITED}

Aebisher NJ, Coulson JC (1990) Survival of the kittiwake in relation to sex, year, breeding experience and position in the colony. J Anim Ecol 59:1063-1071

Anley DG, Girau CR, Roudybush TE, Morrel SH, Utts JM (1981) Petroleum ingestion reduces reproduction in Cassin's auklets. Mar Pollut Bull 12:314-317

Anderson DW, Gress F, Fry MD (1996) Survival and dispersal of oiled brown pelicans after rehabilitation and release. Mar Pollut Bull 32:711-718

Boulinier T, Danchin E (1996) Population trends in kittiwake Rissa tridactyla colonies in relation to tick infestation. Ibis 138:326-334

Butler RG, Harfenist A, Leighton FA, Peakall DB (1988) Impact of sublethal oil and emulsion exposure on the reproductive success of Leach's storm petrels: short and long-term effects. J Appl Ecol 25:25-143

Clark RB (1984) Impact of oil pollution on seabirds. Environ Pollut Ser A Ecol Biol 33:1-22

Coulson JC, Johnson MP (1993) The attendance and absence of adult kittiwakes from the nest site during the chick stage. lbis 135:372-378

Coulson JC, Thomas CS (1985) Changes in the biology of the kittiwake Rissa tridactyla: a 31 -year study of a breeding colony. J Anim Erol 54:9-26

Coulson JC. Thonds CS, Butterfield JEL, Duncan N, Monaghan $P$, Sheddon $C$ (1983) The use of head and bill length to sex live gulls Laridae. lbis 125:549-557

Coulson JC, Wooler RD (1976) Differential survival rates among breeding kittiwake gulls Rissa tridactyla (L.). $\mathrm{J}$ Anim Ecol 45:205-213

Danchin E, Monnat JY (1992) Population dynamics modelling of 2 neighbouring kittiwake Rissa tridactyla colonies. Ardea 80:170-180

Dunnet GM (1982) Oil pollution and seabird populations. Phil Trans R Soc Lond B Biol Sci 297:413-427

Eppley ZA, Rubega MA (1990) Indurect effects of an oil spill: reproductive fallure in a population of South Polar skuas following the 'Bahia Paraiso' on spill in Antarctica. Mar Ecol Prog Ser 67:1-6

Fry DM, Swenson J, Addiego LA, Grau CR, Kang A (1986) Reduced reproduction of wedge-tailed shearwaters exposed to weathered Santa Barbara crude oil. Arch Environ Contam Toxicol 15:45.3 463

Hamer KC, Monaghan P, Uttley JD, Walton P (1993) The influence of food supply on the breeding ecology of kittiwakes Rissa tridactyla in Shetland. Ibis 135:255-264

Harvey S, Phillips JG, Sharp PJ (1982) Reproductive performance and endocrune responses of seabirds to ingested North Sea oil. Grad Stud Texas Tech Unuv 26:537-546

Leighton FA, Peakall DB, Butler RG (1983) Heinz-body haemolytic andemia from the ingestion of crude oil: a primary toxic effect in marme birds. Science 220:871-873

Miles J (1994) Soils, vegetatıon and grazıngs. In: Ritchie W, O'Sullivan $M$ (eds) The environmental impact of the wreck of the Braer. The Scottish Office, Edinburgh, p $127-136$

Monaghan P (1994) Birds. In: Ritchie W, O'Sullivan M (eds) The environmental impact of the wreck of the Braer. The Scottish Office, Edinburgh, p 117-126 
Monaghan P (1996) Relevance of the behaviour of seabirds to the conservation of marine environments. Olkos 77 : $227-237$

Monaghan P, Walton P, Wanless S, Uttley JD, Burns MD (1994) Effects of prey abundance on the behaviour, diving efficiency and time allocation of breeding guillemots. Ibis $136: 214-222$

Peakall DB, Tremblay J, Kinter WB, Miller DS (1981) Endocrine dysfunction in seabirds caused by ingested petroleum. Environ Res 24:6=14

Pearson WH. Woodruff DL, Sugarman PC (1984) The burrowing behaviour of sand lance Ammodytes hexapterus: effects of oll-contaminated sediment. Mar Environ Res $11(1): 17-32$

Ritchie W, O'Sullıvan M (1994) (eds) The environmental impact of the wreck of the Braer The Scottish Office, Edinburgh

Sharp BE (1996) Post-release survival of oiled, cleaned seabirds in North America. Ibis 138:222-228

Stebbing ARD, Dethlefsen V, Carr M (1992) Biological effects

This article was submitted to the editor of contaminants in the North Sea (Results of ICES/IOC Bremerhaven workshopj. Mar Ecol Prou Ser 91:1-361

Uttley JD, Walton P, Monaghan P, Austin G (1994) The effects of food abundance on the breeding performance and adult time budgets of guillemots Uria aalge. lbis 136:204-212

Walsh PM. Brindley E, Heubeck M (1994) Seabird numbers and breeding success in Britain and Ireland, 1993. UK Nature Conservation No. 17, JNCC. Peterborough

Wanless S, Harrıs MP (1992) Activity budgets, diet and breed. ing success of kittiwakes Rissa tridactyla on the Isle of May. Bird Study 39(3):145-154

Wanless S, Monaghan P, Uttley JD, Walton P, Morris JA (1992) A ractio tracking study of kittiwakes Rissa tridactyla foraging under sub-optimal conditions. In: Priede IG, Swlft SM (eds) Wildlife telemetry. Ellis Horwood, Hemel Hempstead

Wright PJ (1996) Is there a conflict between sandeel fisheries and seabirds? A case study at Shetland. In: Greenstreet SPR, Tasker ML (eds) Aquatic predators and their prey. Fishing News Books, Oxford, p 154-165

Manuscript received: May 12, 1997

Revised version accepted: June 6.1997 